\title{
Who and what is their'people'? How British political leaders appealed to the people during the 2019 election
}

\author{
Marino De Luca ${ }^{1}$
}

Accepted: 15 December 2020 / Published online: 7 January 2021

(C) The Author(s) 2021

\begin{abstract}
In recent years, many scholars, mainly those focusing on populism, have analysed the role of 'the people' in politics. This has allowed us to understand how many political actors emphasize the central position of this term. Today, 'the people' has different meanings depending on how politicians use it in specific contexts. In this paper, the reference to 'the people' was measured using the following question: How do political leaders use the word 'people'? The analysis was conducted on Twitter through the study of the accounts of the foremost political leaders in the UK during the 2019 general election campaign. The results highlight three key attitudes related to the use of 'people': a direct and immediate relationship between a leader and a wide people; a calling to a specific people, described as a strong and cohesive group; an appropriation of the voice of the people, grouping people without borders into the classic contraposition between a pure people and the corrupt elite.
\end{abstract}

Keywords People $\cdot$ Politics $\cdot$ UK $\cdot$ Elections $\cdot$ Twitter $\cdot$ Populism

\section{Introduction}

Populism is an ideology focused on recognising 'the people' as the overriding subject of politics. This special status has allowed for an understanding of how political actors have emphasized the people's central position in politics (Ionescu and Gellner 1969; Mény and Surel 2002; Taggart 2000; de la Torre 2010). Populism studies regard the 'ordinary' people as representing a pure, monolithic, and homogeneous group with a positive valorization in an antagonistic relationship against an 'elite' (Canovan 1999; Mudde 2004). In this context, by expressing the general will of the people, the primary purpose of populist figures is to give more power back to the people, who are then able to determine their destiny.

Marino De Luca

m.de-luca@sussex.ac.uk

1 Department of Politics, University of Sussex, Falmer Brighton BN1 9RH, UK 
However, the idea of 'the people' is inevitably bonded by both its 'rhetorical usefulness' and its 'conceptual obscurity' (Canovan 2005). Indeed, from a populist perspective the adversarial relationship between 'the people' and 'the elite' develops a simplistic rhetoric where the existence of a people presupposes the existence of an elite. On the other side, the ambiguity of the 'people' concept has hindered the development of populism as a coherent ideology (Stanley 2008).

Populism appears in a thin-centred form (Taggart 2000; Stanley 2008; Mudde 2004). This means that it needs other ideologies to be understood, or, as regards Western Europe, categorized (Pauwels 2014). It has a chameleonic nature able to adopt the hue of its environment (Taggart 2000).

Other scholars highlight instead the parasitic nature of populism as able to attack the most important 'host', representative democracy, defying it for its exclusive representation of the people (Urbinati 1998). Indeed, often bypassing parliamentary politics, for example, populists appeal directly to the people (Mudde and Kaltwasser 2012). However, although populism, as parasitic, feeds on the democratic host, this relationship causes a dependence able to give to populism a transformative democratic potential (Canovan 1981).

Looking at the symbiotic relationship between parasite and host, populism and democracy, in nature some parasites destroy their host, but most do not. It is clear why. If populism destroys its host, it is also likely to disappear. Instead, parasites normally generate relatively minor damage in their host. Moreover, although populism is often described by 'parasitism' theorists as a negative relationship, other symbiotic relationships have by their nature neutral or positive effects. In some cases, one subject benefits while the other is not affected, as with what biologists call 'commensalism'; in other cases, the symbiotic relationship benefits both subjects, as in 'mutualism'.

In this way, populism can be seen as a thin ideology often associated with more traditional ideologies in a symbiotic relationship where, after an initial negative effect on the host, it is possible to have neutral or even positive mutual effects. Its thinness allows us to analyse it as a complementary ideology that does not overlap other full ideologies but develops alongside them (Stanley 2008). Using this perspective, the ambiguity/obscurity of the key core concept for populism, 'the people', does not help to clarify its relationships, its transformations or even itself. For this reason, this paper focuses on the concept of 'the people' to better understand its role in (and outside) the ideological thinness. What sets the 'people' idea apart from similar ideas, such as class or nation, is indeed its role as a signifier. Laclau argues that 'the people' (and consequently also the elite) is a term with 'empty signifiers' (Laclau 2005), which only gains a specific connotation when it is properly contextualized. In other words, it is the adjective that politicizes the noun (Badiou et al. 2013) by giving it a collective role, a specific identification, or the nature of legitimacy in a political system (e.g. as a sovereign people).

Thus, while the signifier is certainly very flexible, other scholars describing populism in an ideological approach consider it as not totally empty. For example, the moral opposition of 'pure' people vs 'corrupt' elite presupposes a cultural view which gives the signifier a specific content (Mudde 2004); or the use by populists of contents based on the self-perception of features of target communities allows 
the elevation of the concept of 'people' to shared ideals (Taggart 2004); or following full ideologies by adding other meanings to people purity (Canovan 2005); or describing it using other categories, such as class in 'social populism' (March 2012) and nation in 'national populism' (Taguieff 1995).

From these perspectives, although 'the people' is not just a concept of the populism theories, this paper aims to focus on its thinness and complementarity, analysing the 'people' concept as not completely empty, and looking at its different contents depending on how leaders use it in certain circumstances. The term 'the people' is, therefore, better understood by observing the context or the values of the targeted community. For this reason, the concept is the undisputed star in the following research questions: How do political leaders use the word 'people'? What content does the signifier of 'the people' assume?

In order to understand this, an analysis of party leaders on Twitter was conducted from 12 October to 16 December 2019, covering the 2019 UK electoral campaign. The tweet analysis focused solely on the use of the word 'people' by five leaders, excluding non-specific references, e.g. 'citizens', 'we', 'our country', or 'the society'. The choice to analyse only the word 'people' is due to the need to understand the role of 'the people' by focusing on its original meaning and differences.

\section{Populism, populists, and peoples: who and what is 'the people' today, and why study it?}

In populism studies, the term 'people' hides an underlying ambiguity, with several core meanings (Mény and Surel 2002). Indeed, 'people' can refer simultaneously to both the whole and the part. It may also apply, in relation to a heartland (Taggart 2000), to those individuals with a particular nationality, or a part of it, which tries to establish itself as a community based on cultural and/or political features. These essential meanings often intertwine. At other times, they change according to the historical context or different political strategies.

There is a blurring of this polysemic term, 'the people', because the main ideological reference influences different realities in contemporary politics. Indeed, while the classic democratic approach refers to 'the people' in an abstract manner, the populist one adds other specificities, perceiving it as a community of race, culture, identity, blood, and so forth. Indeed, populists appealing to the 'people' attempt to build a homogeneous and undifferentiated group able to exclude 'others' automatically: individuals not belonging to this constructed community. Another problem occurs when the concept is transferred from one country to another, or from a local/ national system to a different context. For example, in Asia, Africa, and the Middle East, populism defines the people based on ethnicity and religion, integrating different individuals-landowners, merchants, bureaucrats, clergy, armed forces (Di Tella 1997).

'The people' may refer to a particular social class, which, although they seem to represent opposite poles in different national societies, have a similar social existence in certain respects. For example, Peronism in Latin America has constructed the people around the working class; in Russia, there are the peasants; and in France, 
the suburban petty bourgeoisie (Mudde and Kaltwasser ). Changes in recent years, due above all to the economic crisis, drove right-wing populism towards the social class dimension, such as the working class in Austria and Switzerland, or the Lepinism of the Front National in France (Kriesi and Pappas 2015). Thus, the key meaning of the term 'people' changes according to the political, historical, and social context, making the people-populism connection difficult and blurred. Indeed, some scholars explain that the term 'people' should not be used to define the populism concept due to its ambiguity, suggesting instead the reference to a heartland, a retrospective construction of an ideal community (Taggart 2004).

The category of 'the people' now has at least three core meanings: (1) a unified entity with legitimate power in whose name laws are produced and implemented; (2) the social body that shares the same territory in a specific historical period; and (3) the socio-political group that claims and achieves political power through movements, parties, and their representatives (Urbinati 2019).

In the first meaning, 'the people' is used in a formal way to legitimize legal rule, which is impartial and fair. Thus, the term 'the people' reaches the highest inclusiveness level, inasmuch as it includes all the individuals of the same state, which become the ground of its authority (Espejo 2011). Since the first medieval enforcing of Roman Law, the people's central role has become 'sovereign' in the modern theories of representation and 'constitutionalized' between the eighteenth and nineteenth centuries through the first constitutions made in their name, as the most crucial source of authority in the state (Espejo 2017).

In the second meaning, 'the people' is a sociological category treated as an ethical entity, and an ideological tool often used to justify protection from 'others', both external and internal enemies (Urbinati 2019). In this case, the people become a portfolio of populations held together by the nation. Indeed, 'the people' is used as artificial unity to stabilize a political order (Espejo 2017). In this way, the people have a symbolic reference, often associated with ethnicity or an ethnic group (Smith 2003).

In the third meaning, 'the people' is indeterminate and characterized by a collective function in the name of which movements and political parties claim to speak for 'the people'. Through a political competition, where it is claimed that majority interests are prioritized against minorities, political movements organize themselves to claim their rights or to redress wrongs done to those they represent (Espejo 2017; Urbinati 2019).

Populism is mainly present in the last two core meanings. Indeed, the majoritarian rule becomes necessary to the populist perspective as a means by which the 'general will' can be achieved (Canovan 2005; Kriesi and Pappas 2015). In this view, the people are perceived as one body with distinctly defined boundaries, challenging to cross. A distinction between those who belong to this group and those not included is necessary in the ideological framework. As to the nature of these boundaries, popular sovereignty implies two kinds. The first relies on a view of the people as a legitimate sovereign. In this case, the people are directly opposed to the elites, which illegitimately use power in the name of the people. The second also presupposes a territorial definition, reinforcing an identity narrowed down to the nation (Canovan 2005). 
The people become a 'homogenous' (Mudde 2004) or 'monolithic' (Taggart 2000) group without internal differences (Jagers and Walgrave 2007), composed of 'common men', ordinary people. This view is also reflected in Taggart's conceptualization of the heartland $(2000,2004)$, a place that, unlike utopian conceptions, is idealized around an imagined version of the past as that which has been lost in order to imagine a political vision blurred around the boundaries. This ambiguity is used by populist leaders who appeal to the people to support their views and legitimize their role. However, political leaders appeal to the people in different ways, and the high level of unity of the people does not necessarily correspond to a similar approach by politicians; it is necessary to understand and analyse this. Thus, the heartland can mean a number of considerably different things to different politicians. As Mudde (2004) notes, for the British National Party, the heartland was composed of 'the native British people', a group with precise and specific boundaries that differs from both Taggart's definition of heartland and Jagers and Walgrave's approach to the role of 'the people'.

To sum up, populism needs the notion of 'the people' in at least four aspects. First, the populist approach is people-centred (Rooduijn 2014), in order to declare the supremacy of the people themselves (Mény and Surel 2002), i.e. popular sovereignty, and claim the 'government of the people, by the people, for the people' (Canovan 1999, p. 10). Second, populism uses the people in an antagonistic way, making a permanent opposition between 'the right people', the 'good', and 'the wrong people', corrupt and 'bad' (Mudde 2004). Third, democratic legitimacy is related to the interests of the collective, the many, in opposition to the interests of the establishment, the few, in order to change the status quo (Urbinati 2019). Fourth, the populist movement or party claims to interpret the 'general will' of the people, representing the real idea of the people inasmuch as it is able to understand their will (Mudde 2004).

Following this key core of 'the people' in populism theories, this article aims to analyse, through the appeal to the people by the leader, the effective role of the people, how it is employed and what it is used to refer to.

\section{Methods and data}

This study aims to describe how 'the people' are identified by each leader during the electoral campaign, paying attention to the criteria according to which some people could be part of a specific group and other people left out. According to the literature above, this article aims to respond to the following research questions: How do political leaders use the word 'people'? What content does the signifier of 'the people' assume? Is it possible to identify associations between the term 'people' and the foremost political leaders in the UK? How do these associations impact the way in which the people are appealed to and idealized?

The analysis was conducted from 12 October to 16 December 2019 on Twitter through the study of the five main political leaders-Boris Johnson, Jeremy Corbyn, Jo Swinson, Nicola Sturgeon, and Nigel Farage_-during the 2019 UK electoral campaign. 
The decision to select the UK as a case study is best understood in the light of the transformations facing Europe after the Brexit referendum. Furthermore, the UK in the Brexit context has shown even more the thin-centredness of populism as an ideology (Freeden 2017). Moreover, in recent years, several scholars have highlighted the UK as a location where populisms, both left and right, strongly overlap with their underlying ideology (March 2017). Although in the past analyses claimed that the programmes of mainstream parties had not become more populist (Rooduijn et al. 2014), in recent years even established parties have experimented with populism. In the case of Labour, with Corbyn the claim was made that the party moved more to the left and followed political approaches that can be classified as close to populism (Watts and Bale 2019).

Within this scenario, the UK displays several elements of interest. In July 2019, after Theresa May's resignation, Boris Johnson was selected as the Conservative leader and named Prime Minister. In this new context, Johnson failing to approve a revised withdrawal deal by the end of October led to a snap election on 12 December 2019. Thus, the 2019 election represented one of the highest moments of political conflict in the UK. Given that the exit date from the European Union was set for the end of January 2020, Johnson needed to gain a clear majority in order to achieve his withdrawal deal.

Although the electoral campaign started in the first week of November, the period from 12 October to 16 December allows analysis of the time between two months before and the week after the UK elections. In this respect, three further aspects should be considered.

First, political communication has become a key factor in the vision and performance of populist movements and leaders. In this media context, the leader's ability to communicate their messages has reached new levels, due also to the erosion of the monopoly that mainstream media and traditional political actors had held over this aspect. Moreover, social network platforms such as Twitter have provided political leaders with an opportunity to act in an unmediated way (Klinger and Svensson 2015), speedily and virally (Jacobs and Spierings 2016, pp. 21-22), and directly involving the people (Klinger and Svensson 2015; Tromble 2016), through short, straightforward communication (Engesser et al. 2017) using everyday language (Bos and Brants 2014). This allows the creation of a grouping of followers in the leaders' likeness, to which the party communicates or gives attention, embodying it and becoming their voice.

Second, during electoral campaigns successful appeals to the people are indispensable for high electoral performance so can be more frequent and sustained. Third, the 2019 electoral campaign focused on the relationship with the European Union. This aspect is relevant to this research. Indeed, many scholars have highlighted that EU institutions are often the main targets of the member states' blame-shifting strategies, becoming an ideal 'issue' on which anti-establishment positions can increase. Euroscepticism has often become an anti-elite topic for populists, and one of the most meaningful symbols of 'populist potential' (Taggart 2004; Van Kessel 2015).

In terms of data, the full content of the tweets of the five leaders in which the word 'people' appeared was analysed via Nvivo software. A total of 1,929 tweets were identified and collected, of which 226 contained the word 'people'. Per each 
unit of analysis, in addition to the unit's identification items (date, username, text length, number of retweets, hashtag, mentions), four key variables were coded: the unit's primary topic and central issue, the communicative strategy, and the people adjective.

The primary topic identifies the main topic upon which the unit is centred (e.g. campaign issues, policy issues, political issues, and current affairs) while the unit's central issue identifies the problem covered by the tweets (e.g. education, elections, foreign policy, etc.), which become the two first most important things in analysing the tweet's content (Ausserhofer and Maireder 2013; Conway et al. 2015; Davis et al. 2016).

The communicative strategy identifies the communication technique implemented, e.g. emotional (Bos et al. 2011, 2013; Mazzoleni et al. 2003; Van Santen and Van Zoonen 2010), instrumental (Krämer 2014), intimate (Stanyer 2012), simplification (Alvares and Dahlgren 2016; Caiani and Graziano 2016), taboo breaker (Caiani and Graziano 2016; Krämer 2014; Moffitt and Tormey 2014), and rationalization strategies.

The adjective used to connote the word 'people' refers to the semantic process by which the people gain political significance. In effect, the adjectives used to describe it allow for the politicization of the noun in a collective vision (Badiou et al. 2013). The adjective used to connote the people is also able to produce identification or describe the nature of the legitimacy of a political system, e.g. sovereign people. Thus, depending on the type of adjective, people can have many characterizations. It should be remarked, however, that by coding this variable, the purpose was not exclusively to classify adjectival patterns. Instead, it was used to analyse any item (adjectives, nouns, adverbs) helpful to describe better or connote the term 'the people' (e.g. the people of voters, the people of workers, etc.).

From this perspective, an analysis of the descriptive statistics was used to explain the general features in the research. Afterwards, the relationship between variables was tested to understand the possible associations between the adjective used to connote 'people' and the leader, to understand how 'people' is contextualized in every single tweet. In this regard, correspondence analysis (De Luca and Ciaglia 2017; Greenacre 2017) was used to aid analysis of multinomial qualitative variables by reducing complexity through optimal scaling ${ }^{1}$ to identify the scores (i.e. the coordinates) of the modalities of the row variable (the leader) against a bi-dimensional space based on the modalities of the column variables (the adjective).

\footnotetext{
1 The objective is to maximize the variance between alternative modalities, by attributing 0 to the mean of the medium profile and 1 to the variance of the medium profile.
} 


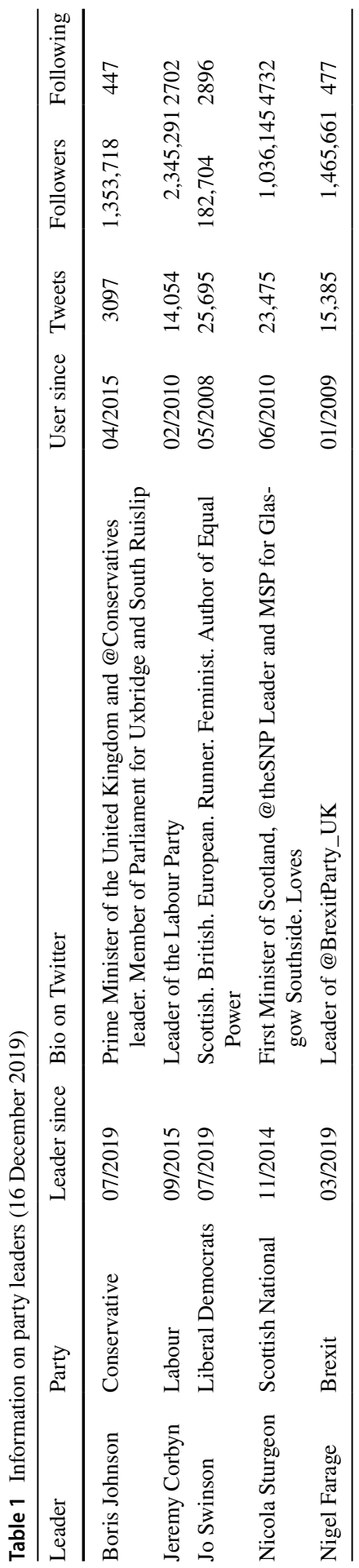


Table 2 'People' in the leaders' tweets (from 12 October 2019 to 16 December 2019)

\begin{tabular}{llllllll}
\hline Leader & Party & Tweets $(N)$ & $\begin{array}{l}\text { 'People' } \\
\text { tweets } \\
(N)\end{array}$ & $\begin{array}{l}\text { 'People' } \\
\text { tweets } \\
(\%)\end{array}$ & $\begin{array}{l}\text { Hashtag } \\
\text { used }(N)\end{array}$ & $\begin{array}{l}\text { Avg char- } \\
\text { acters } \\
(N)\end{array}$ & $\begin{array}{l}\text { Avg retweet } \\
(N)\end{array}$ \\
\hline $\begin{array}{l}\text { Boris Johnson } \\
\begin{array}{l}\text { Jeremy Cor- } \\
\text { byn }\end{array}\end{array}$ & $\begin{array}{l}\text { Conservative } \\
\text { Labour }\end{array}$ & 550 & 57 & 10.4 & 21 & 179 & 906 \\
$\begin{array}{l}\text { Jo Swinson } \\
\begin{array}{l}\text { Liberal demo- } \\
\text { crats }\end{array}\end{array}$ & 203 & 26 & 12.8 & 22 & 198 & 742 \\
$\begin{array}{l}\text { Nicola Stur- } \\
\text { geon }\end{array}$ & $\begin{array}{c}\text { Scottish } \\
\text { national }\end{array}$ & 212 & 10 & 4.7 & 6 & 214 & 4121 \\
$\begin{array}{l}\text { Nigel Farage } \\
\text { Total }\end{array}$ & $\begin{array}{c}\text { Brexit } \\
\text { - }\end{array}$ & 208 & 17 & 8.2 & 0 & 154 & 1985 \\
\hline
\end{tabular}

\section{Results}

\section{Preliminary analysis}

In general, the five leaders have used Twitter intensively during their political careers. Table 1 shows a snapshot of their profile on the last day of analysis. Jo Swinson has been a Twitter user for the longest time, since 2008, while the most recent to use the platform is Boris Johnson, since 2015. Among the most followed is Corbyn with followers in excess of 2.3 million, Johnson and Farage reaching 1.4 million and Sturgeon just over one million. Swinson, despite her longevity as a Twitter user, has just 182,000 followers.

Table 2 includes information about the use of Twitter by the five leaders during the period under analysis. It shows the number of tweets and, above all, the percentage containing the word 'people'. Moreover, by analysing the 'people' tweets, the user's behaviour is observed through the analysis of hashtag use, the average length of the tweet text, and the average number of retweets.

Looking at the data from 12 October to 16 December 2019, the political frontrunner Boris Johnson published 550 tweets, of which $10.4 \%$ contain a reference to the word 'people'. In his 'people' tweets, Johnson used 21 hashtags, with an average tweet length of 179 characters. The average number of retweets was 906. Jeremy Corbyn, the Leader of the Labour Party, most commonly used the word 'people' (15.3\%). Corbyn used 30 hashtags with an average per tweet of 214 characters. He was retweeted, on average, 4,121 times. Jo Swinson, although one of the most longstanding Twitter users, during the period was among the least active of the five leaders, and also the least retweeted, with an average of only 742 retweets. She used 22 hashtags and an average of 198 characters per tweet. Her 'people' tweets reached 12.8\%. For Nicola Sturgeon, the First Minister of Scotland and the SNP leader, among the 212 tweets published she had the lowest proportion containing the word 'people' (4.7\%). Sturgeon used six hashtags and among the five leaders had the highest average number of characters: 253 of a maximum of 280 characters. She had a high retweet average of 2,456. Finally, Nigel Farage, Leader of the Brexit Party: of 
Table 3 Issues in the 'people tweets' (\%)

\begin{tabular}{lllllll}
\hline & Johnson & Corbyn & Swinson & Sturgeon & Farage & Total \\
\hline Brexit & 26.7 & 6.8 & 66.7 & 8.3 & 20 & 18.9 \\
Campaign (storytelling) & 2.7 & 33.3 & 3.7 & - & 40 & 21.4 \\
Economy \& fiscal & 17.3 & 14.3 & - & - & 10 & 12.8 \\
Environment & - & 4.1 & 3.7 & 8.3 & - & 2.8 \\
Foreign countries & 1.3 & 2.7 & - & 8.3 & - & 2.1 \\
Improve country & 8 & 8.2 & 3.7 & 8.3 & 10 & 7.8 \\
Workforce & - & 7.5 & - & - & - & 3.9 \\
NHS & 13.3 & 12.2 & - & 16.7 & - & 10.7 \\
Rights (e.g. minority, women, & - & 7.5 & 18.5 & 50 & - & 7.8 \\
$\quad$ disabled, etc.) & & & & & & \\
Education (e.g. school system) & 14.7 & - & - & - & - & 3.9 \\
Security & 16 & 2.7 & - & - & 10 & 6.4 \\
Terrorism & - & 0.7 & 3.7 & - & 10 & 1.4 \\
Total (N) & 75 & 147 & 27 & 12 & 20 & 281 \\
\hline
\end{tabular}

Percentages and totals are based on responses/items

the 208 tweets published, 8.2\% had a reference to 'people'. None of the tweets considered had a hashtag and they were shorter than those of the other leaders with an average of 154 characters. They had an average retweet rate of 1,985.

\section{The contents, focus, and strategies of the campaigns}

Several scholars have highlighted the importance of analysing the topic and issues covered on Twitter (Ausserhofer and Maireder 2013; Conway et al. 2015; Davis et al. 2016). An election campaign presents at least five different types of topic. First, issues related to the campaign, referring to the management or performance of the campaign in which the meeting and political events are narrated. Second, policy issues, referring to specific topics in which proposals to resolve problems are highlighted. Third, political issues, focusing on politics, ideologies, and issues regarding the relationships among parties and institutions. Fourth, current affairs, referring to non-political topics that are still current events (sport, events, news, etc.). Fifth, personal issues, such as personal reflections or issues in politicians' private lives.

The data analysed in this article covers only four of the five commonly used categories. Indeed, among the 226 'people' tweets analysed, those related to campaign issues - the management or performance of the campaign-reached $39.8 \%$ of the sample, followed by the policy issues $(27.4 \%)$, political issues $(21.7 \%)$, and current affairs $(11.1 \%)$. None of the tweets analysed refers to the private life of politicians. This does not mean that they do not exist, but simply that in the sample selected based on 'people' there are no tweets associated with this category.

As regards the specific issue of each tweet, Table 3 shows the differences among the five leaders. Although the main topic has been campaign storytelling $(21.4 \%)$, Brexit occupied a prominent role $(18.9 \%)$. 
Among the leaders, Swinson reached the highest value on Brexit (66.7\%), seeing the whole electoral campaign as related to the opportunity to establish a second referendum to allow the 'Remainers' another possibility. Johnson used Brexit (26.7\%) to talk mainly about the British priorities in his programme: the NHS, security, and education/schools. Following this, Farage (20\%), Sturgeon (8.3\%), and finally Corbyn (6.8\%) were the candidates with the lowest percentage of 'people' tweets on Brexit. Corbyn mainly criticized Johnson's deal.

The NHS issue was a key point of concern for Sturgeon (16.7\%), Johnson (13.3\%), and Corbyn (12.2\%). Security was an issue dealt with by the most rightwing leaders, while the economy was central above all to the two main challengers, Johnson and Corbyn, followed by Farage. The work issue was considered only by Corbyn, although in a small quantity (7.5\%), and education only by Johnson $(14.7 \%)$. The general issue 'improve country' was covered by all the candidates except for Swinson, although for Sturgeon, naturally enough, it was about how to improve Scotland.

Another interesting aspect was the issue of rights, namely concerning minorities, disabled people, women, etc., which was the main issue for Sturgeon (50\%). It was one of the most important topics for Swinson (18.5\%) and partly also for Corbyn (7.5\%). Minor issues, related to the candidates' programmes or strategy, were, for example, for Farage the terrorism problem (10\%), for Sturgeon Scotland's independence (see 'improve country', 8.3\%), and, above all, for Corbyn the storytelling of his electoral campaign, focusing on his activists and supporters (33.3\%).

From this perspective, the issues raised during the electoral campaign also become a reason to consider specific communication strategies using populist rhetoric. Several scholars have shown that the key components of populism-anti-elitism, general will, the opposition between pure people and the corrupt elite-have to be considered differently from populist styles (Bos et al. 2010). Mainstream political parties more regularly use the performance style of populists than the more traditional components of their rhetoric. The aim is to have an ordinary style (Mazzoleni et al. 2003), characterized by simplicity, and clarity (Taggart 2000). For this reason, it becomes fundamental for contemporary parties to organize all communicative strategies around a central (charismatic) leader (Weyland 2001).

These strategies refer to the communication technique implemented by parties and leaders and are divided into: emotional strategies that rely on common feelings (Bos et al. 2011 2013; Mazzoleni et al. 2003; Van Santen and Van Zoonen 2010); instrumental strategies that exploit specific, generally current, events, supporting political positions using inductive reasoning (Krämer 2014); intimate strategies based on personification with episodes focusing on the private sphere (Stanyer 2012); simplification strategies that face complex problems by offering simple solutions (Alvares and Dahlgren 2016; Caiani and Graziano 2016); taboo-breaker strategies that shake up the norms of political correctness/politeness (Caiani and Graziano 2016; Krämer 2014; Moffitt and Tormey 2014); and rationalization strategies around a specific concept based on common reason or scientific evidence. Our data shows (Table 4) that in the period under analysis the most used strategies were emotional $(64.2 \%)$, followed by instrumental (26.5\%), simplification (4.9\%), rationalization 
Table 4 Strategies in the 'people tweets' (\%)

\begin{tabular}{lllllll}
\hline & Johnson & Corbyn & Swinson & Sturgeon & Farage & Total \\
\hline Emotional & 52.6 & 81.0 & 23.1 & 60.0 & 52.9 & 64.2 \\
Instrumental & 33.3 & 13.8 & 50.0 & 40.0 & 47.1 & 26.5 \\
Simplification & 14.0 & 2.6 & - & - & - & 4.9 \\
Rationalization & - & 1.7 & 19.2 & - & - & 3.1 \\
Intimate & - & 0.9 & 7.7 & - & - & 1.3 \\
Taboo breaker & - & - & - & - & - & - \\
Total (N) & 57 & 116 & 26 & 10 & 17 & 226 \\
\hline
\end{tabular}

Table 5 Summary of adjective vs leader

\begin{tabular}{|c|c|c|c|c|c|c|c|c|}
\hline \multirow[t]{2}{*}{ Dimension } & \multirow[t]{2}{*}{$\begin{array}{l}\text { Singular } \\
\text { value }\end{array}$} & \multirow[t]{2}{*}{ Inertia } & \multirow[t]{2}{*}{ Chi square } & \multirow[t]{2}{*}{ Sig } & \multicolumn{2}{|c|}{ Proportion of inertia } & \multicolumn{2}{|c|}{$\begin{array}{l}\text { Confidence singu- } \\
\text { lar value }\end{array}$} \\
\hline & & & & & $\begin{array}{l}\text { Accounted } \\
\text { for }\end{array}$ & $\begin{array}{l}\text { Cumula- } \\
\text { tive }\end{array}$ & $\begin{array}{l}\text { Standard } \\
\text { deviation }\end{array}$ & $\begin{array}{l}\text { Corre- } \\
\text { lation } 2\end{array}$ \\
\hline 1 & 0.668 & 0.446 & & & 0.569 & 0.569 & 0.048 & 0.141 \\
\hline 2 & 0.453 & 0.205 & & & 0.262 & 0.831 & 0.071 & \\
\hline 3 & 0.329 & 0.108 & & & 0.138 & 0.969 & & \\
\hline 4 & 0.155 & 0.024 & & & 0.031 & 1.000 & & \\
\hline Total & & 0.783 & 177.070 & $0.000^{\mathrm{a}}$ & 1.000 & 1.000 & & \\
\hline
\end{tabular}

${ }^{\mathrm{a}} 44$ degrees of freedom

(3.1\%), and intimate $(1.3 \%)$. As for emotional strategies, Corbyn reached the highest value $(81 \%)$, while for instrumental strategies Swinson reached $50 \%$.

\section{The adjective and the people}

As stated in the previous section, the meaning of 'people' develops around several key aspects. Of these, one describes a socio-historical body that lives in a specific territory, and another conveys a political collective that claims policies. In both cases, the problem of a body within borders has come to light, dividing who belongs to this body and who is not included. In this context, the analysis of the adjective used to politicize the neutral term 'people' becomes essential to understand borders' characteristics.

A correspondence analysis was used to evaluate the association between the leader and the adjective that politicized the people. A preliminary analysis (Table 5) of the row-normalized correspondences (44 degrees of freedom) shows a significant chi square $2(\mathrm{p}<0.000)$, whose value is 177.070 . This value shows a strong association between the two variables' modalities, allowing us to reject the hypothesis of independence between variables. Furthermore, the inertia for the two dimensions 
Table 6 Overview column points

\begin{tabular}{|c|c|c|c|c|c|c|c|c|c|}
\hline \multirow[t]{3}{*}{ Adjective } & \multirow[t]{3}{*}{ Mass } & \multicolumn{2}{|c|}{ Score in dimension } & \multirow[t]{3}{*}{ Inertia } & \multirow{2}{*}{\multicolumn{2}{|c|}{$\begin{array}{l}\text { Contribution of } \\
\text { point to inertia } \\
\text { of dimension }\end{array}$}} & \multirow{2}{*}{\multicolumn{3}{|c|}{$\begin{array}{l}\text { of dimension to inertia } \\
\text { of point }\end{array}$}} \\
\hline & & \multirow[t]{2}{*}{1} & \multirow[t]{2}{*}{2} & & & & & & \\
\hline & & & & & 1 & 2 & 1 & 2 & Total \\
\hline British & 0.097 & -2.140 & 0.371 & 0.202 & 0.446 & 0.013 & 0.986 & 0.014 & 1.000 \\
\hline Elite & 0.044 & 0.602 & -1.559 & 0.034 & 0.016 & 0.108 & 0.208 & 0.641 & 0.849 \\
\hline Divisional & 0.053 & 1.046 & 0.578 & 0.070 & 0.058 & 0.018 & 0.371 & 0.052 & 0.423 \\
\hline Generic & 0.385 & 0.208 & -.580 & 0.048 & 0.017 & 0.130 & 0.155 & 0.553 & 0.708 \\
\hline Generational & 0.058 & 0.413 & 0.671 & 0.011 & 0.010 & 0.026 & 0.413 & 0.502 & 0.915 \\
\hline Other & 0.022 & 0.254 & -0.276 & 0.017 & 0.001 & 0.002 & 0.038 & 0.020 & 0.058 \\
\hline Our & 0.018 & -.830 & -0.326 & 0.008 & 0.012 & 0.002 & 0.643 & 0.046 & 0.688 \\
\hline Voting & 0.102 & 0.894 & 2.412 & 0.170 & 0.081 & 0.592 & 0.213 & 0.713 & 0.926 \\
\hline Supporting & 0.053 & 0.829 & -1.390 & 0.050 & 0.037 & 0.103 & 0.323 & 0.419 & 0.742 \\
\hline Weak & 0.071 & 0.757 & 0.004 & 0.030 & 0.041 & 0.000 & 0.601 & 0.000 & 0.601 \\
\hline Wonderful & 0.027 & -.757 & 0.248 & 0.022 & 0.015 & 0.002 & 0.305 & 0.015 & 0.321 \\
\hline Working & 0.071 & -1.939 & 0.286 & 0.120 & 0.266 & 0.006 & 0.985 & 0.010 & 0.995 \\
\hline Active total & 1.000 & & & .783 & 1.000 & 1.000 & & & \\
\hline
\end{tabular}

Rzow principal normalization

explains $83 \%$ of the model. Standard deviation is 0.048 and 0.071 for the two models respectively. The correlation is low at 0.141 .

On the other hand, an analysis of the columns reveals several interesting elements as regards the two dimensions (Table 6). The scores of the column modalities enable us to identify the two dimensions on a spatial map. Dimension 1 is positively characterized by the adjective 'divisional' (1.046) and negatively characterized by 'British' (-2.140). Dimension 2 displays positive values about 'voting' (2.412) and negatively associated with 'elite' (- 1.559). In short, Dimension 1 was defined as the social body that shares the same territory in a specific historical period, called the 'socio-historical dimension' and characterized by the opposition 'divisional' (+) vs 'British' (-), while Dimension 2 was defined as the socio-political group that claims and achieves political power through movements, parties, and their representatives, called the 'socio-political dimension' and characterized by the opposition 'voting' (+) vs 'elite' (-).

Row principal normalization allowed row modalities (leader) to be interpreted against the two dimensions that have been drawn from the analysis. The next step was to calculate the angle formed by the two vectors originating in the point $(0,0)$, and the directions determined by the coordinates of the row and column points, around which association is calculated. The formula is as follows:

$$
\theta=\left[\arccos \left(\frac{r^{\prime} c}{\|r\| \times\|c\|}\right)\right] \times\left(\frac{180}{\pi}\right)
$$


Table 7 Size of angles and associations between row and column modalities

\begin{tabular}{lllllr}
\hline Column modality & \multicolumn{5}{l}{ Row modality } \\
\cline { 2 - 6 } & Johnson & Corbyn & Swinson & Sturgeon & Farage \\
\hline British & $2.06^{\mathrm{a}}$ & $152.16^{\mathrm{b}}$ & 111.42 & $133.49^{\mathrm{b}}$ & 83.35 \\
Elite & 118.90 & 31.19 & $127.62^{\mathrm{b}}$ & 105.55 & 37.62 \\
Divisional & $143.29^{\mathrm{b}}$ & 66.62 & 29.81 & $7.74^{\mathrm{a}}$ & 135.43 \\
Generic & 117.53 & 32.57 & $128.99^{\mathrm{b}}$ & 106.92 & $36.24^{\mathrm{a}}$ \\
Generational & 113.85 & 96.06 & $0.37^{\mathrm{a}}$ & $21.71^{\mathrm{a}}$ & $164.87^{\mathrm{b}}$ \\
Other & $140.41^{\mathrm{b}}$ & $9.69^{\mathrm{a}}$ & 106.11 & 84.04 & 59.12 \\
Our & 29.21 & 120.88 & $142.69^{\circ}$ & $164.77^{\mathrm{b}}$ & 52.07 \\
Voting & 102.56 & 107.35 & $10.92^{\mathrm{a}}$ & 33.00 & $176.16^{\mathrm{b}}$ \\
Supporting & 128.59 & $21.50^{\mathrm{a}}$ & 117.93 & 95.86 & 47.31 \\
Weak & $171.92^{\mathrm{b}}$ & 37.99 & 58.44 & 36.37 & 106.80 \\
Wonderful & $10.37^{\mathrm{a}}$ & $160.47^{\mathrm{b}}$ & 103.10 & 125.18 & 91.66 \\
Working & $0.63^{\mathrm{a}}$ & $150.72^{\mathrm{b}}$ & 112.85 & $134.93^{\mathrm{b}}$ & 81.91 \\
\hline
\end{tabular}

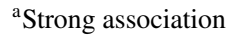

${ }^{\mathrm{b}}$ Weak association

where $\|r\|$ is the length of the vector originating from $(0,0)$ whose direction is defined by the coordinates of the row point $r$. It can be calculated using Pythagoras' theorem. $\|c\|$ is the length of the vector originating from $(0,0)$, whose direction is defined by the coordinates of the column point $c$. It, too, can be calculated using Pythagoras' theorem. Finally, $r^{\prime} \mathrm{c}$ is the vector scalar product.

$$
\sum_{q} r_{q} \times c_{q}
$$

The calculation of the angles (and of the type of association with a certain adjective) allows us to trace a profile of the five leaders (Table 7). ${ }^{2}$ Johnson displays a significant association with adjectives related to 'British', as well as with 'wonderful' and 'working'. Conversely, he is weakly associated with 'divisional', 'other', and 'weak'. Corbyn shows close ties with identity adjectives which emphasise the importance of belonging to a group rather than differences from other groups. In this respect, identity is treated in a positive manner. The adjectives are 'other' and 'supporting'. The degree of association is weak with 'British', 'wonderful', and 'working'. For Swinson the analysis displays a close connection with such adjectives as 'generational' and 'voting'. Association is instead weak with 'elite', 'generic', and 'our'. Sturgeon has a strong association with adjectives such as 'divisional' and 'generational', with weak associations with 'British', 'our', and 'working'. Finally,

\footnotetext{
${ }^{2}$ An acute angle identifies a positive association, a right angle a null association, an obtuse angle a negative association.
} 
Farage shows a positive association with a generic use of the term 'people', and is weakly associated with 'generational' and 'voting'.

\section{The content analysis}

The data allows us to introduce a possible explanation of the use of 'people' by the UK leaders during election time. Boris Johnson, who despite being the leader joined Twitter most recently in 2015, demonstrated that he could manage social media, especially after his appointment as Conservative leader in July 2019 when there was a spike in the number of both followers and political attacks. During his electoral campaign, he used three main communicative strategies on Twitter: emotional, instrumental, and simplification. This allowed him to manage the different situations both as party leader and as PM to discuss the Brexit deal and the British priorities in his programme, such as the NHS, security, and education. Numerous examples could be cited. One of the most interesting is in a tweet published on 11 November 2019 where Johnson uses the word 'people' to talk about British priorities: 'The British people have had enough delay \& uncertainty. I want us to \#GetBrexitDone and spend next year focusing on the issues that matter-tackling violent crime, investing in our NHS \& schools, and strengthening our economy'.

Moreover, although Corbyn was closer to work issues in his debates, it is Johnson who speaks about the 'working people'. On 12 November 2019 he used the same language as in a previous tweet: 'We can only invest in our great public services if we support the entrepreneurs, businesses and hardworking people who get up each day to build our strong economy', and on 20 November 2019: 'Today I've announced that under a majority Conservative government, we will cut taxes for millions of working people on low and middle incomes. I will cut taxes for working people'. Finally, for Johnson, the people became 'beautiful', 'amazing', and 'passionate' in his tweets, especially when he talks about meetings where people were 'enthusiastic' about his candidacy and his programme. On 22 November 2019, he writes: 'We live in an incredible country. Everywhere I go, I meet people who are enthusiastic and passionate about this country's future and what we can achieve. Let's get Brexit done!'.

As regards Jeremy Corbyn, among the five candidates he is the most followed. Moreover, he was also the most active in Twitter use both for the highest number of tweets and for the highest percentage related to the word 'people'. His communicative strategy is mainly oriented to the emotional to rely on common feelings, which often coincides with an appeal to his supporters. However, Corbyn was the candidate with the lowest percentage of tweets on Brexit, used above all to criticize Johnson's deal. It is particularly interesting to refer to a tweet published on 31 October 2019, where he declares: 'Boris Johnson has spent months promising we'd leave the EU today. The failure to do so is his and his alone. Labour will get Brexit sorted by giving the people the final say within six months with the choice of a credible leave deal or remain. And we'll carry out what you decide'. Thus, in Corbyn's tweets, his people are made up of militants and supporters, as on 30 October 2019: 


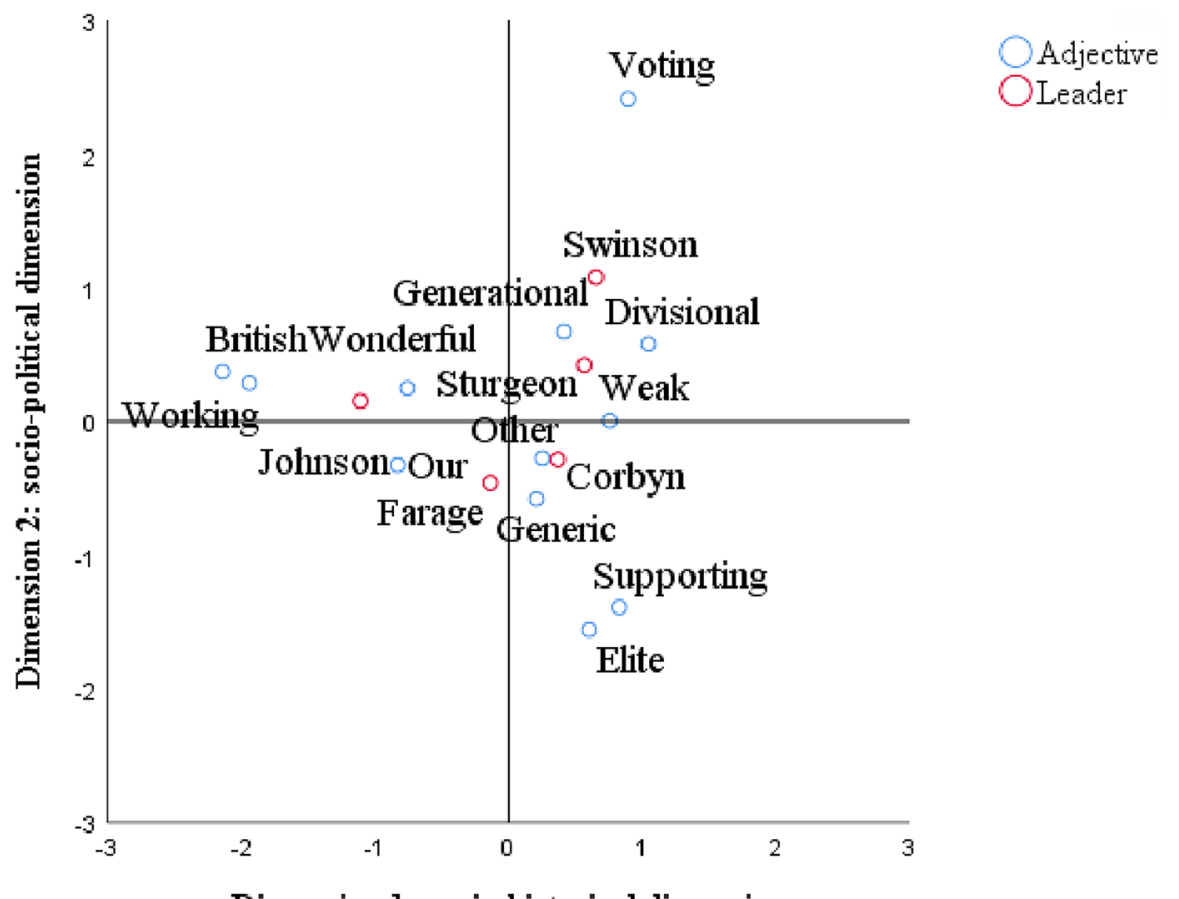

Dimension 1: socio-historical dimension

Fig. 1 Correspondence analysis of adjective and leader

'The General Election is here. We are a party of half a million people. We want you out there, door to door, talking to your neighbours about how we will transform our country'.

Nonetheless, in some cases, Corbyn used 'the people' in a generic way, without any adjective, such as on 7 December 2019: 'The people telling you we can't solve the climate crisis helped create it. The people telling you they won't sell off our NHS can afford private healthcare. The people telling you we can't scrap tuition fees went to university for free. They are not on your side'. In other cases, Corbyn embraces the people in their weakness by transforming himself into the paladin able to defend them. For example, on 1 November 2019, he attacks the more affluent people: 'There are 150 billionaires in the UK while 14 million people live in poverty. In a fair society there would be no billionaires and no one would live in poverty'.

As for the Liberal Democrats' leader, Jo Swinson, although she was the most long-standing user of Twitter, since 2008, she had the lowest number of followers and tweets published during the period under analysis. However, after Corbyn she had the highest percentage of tweets about people. Her communicative strategies were mainly used in an instrumental way mixed up with the rationalization of main issues. Indeed, she used a specific event, like Brexit, in order to support her political position: the Brexit referendum was wrong, and the 'voting' people now needed a second referendum to allow the 'remainers', new and old, another possibility. On 27 November 2019, she declared: 'Brexit will damage the livelihoods of people, 
families, and communities across the whole United Kingdom. Every vote for @LibDems is a vote to \#StopBrexit. Together, we can build a \#BrighterFuture. Join the fight to Stop Brexit now'. Further topics used by Swinson in a strategic way to attack her competitors were the generational issue, above all regarding young people, and the rights issue, concerning minorities, disabled people, women, etc. On 3 December 2019 she published a tweet against Johnson using Trump's visit: 'Donald Trump is man who has boasted about sexually assaulting women, whose policies discriminate against people from ethnic minorities and different religious backgrounds. A vote for Boris Johnson is a vote for Donald Trump's politics. We must \#StopBoris \& \#StopBrexit' (Fig. 1).

As regards the leader of the Scottish National Party, Nicola Sturgeon, data, shown in the previous sections, highlights how, despite having a significant number of followers on Twitter, her activity on the platform was limited during the campaign. Of the five candidates, Sturgeon was the politician who used the word 'people' least of all. In the few cases analysed, Sturgeon focused mainly on 'young' people and general rights, for example, on 21 November 2019: 'Great \#GE19 visit with @ AnneMcLaughlin today to "Possibilities", a fantastic organisation helping people with disabilities in many different ways. Thanks to all for the lovely welcome'. However, her emotional-based communication strategy described people in a territorial way. While the other candidates endeavoured to maintain an imaginary and collective unit, Sturgeon mainly focused on the priorities of the Scottish people. On 8 November 2019, she wrote 'escape Brexit and put Scotland's future into Scotland's hands'. Thus, the type of contact between the leader and her people was the cornerstone around which the communication rotated, and the function of the SNP leader primarily aimed to create identification between the leadership and the people to whom she spoke. In this way, falling within the circle (of the people) became a crucial factor.

Sturgeon talked about her people in different ways. First, against Johnson on 3 November 2019, when he rejected any request to hold a referendum on Scottish independence: 'I wonder if at any point during \#GE19, the media will subject this unsustainable and undemocratic position to any serious scrutiny? You know, instead of just asking if they will "allow" actually asking them to justify saying they will ignore the votes of the Scottish people'. Second, as First Minister of Scotland, on 10 November 2019: 'Today on behalf of the people of Scotland I will lay a wreath at the Stone of Remembrance in Edinburgh, in memory of all those who gave their lives in conflict. I will do so with the utmost gratitude and respect for the sacrifice and courage of our armed forces. \#RemembranceDay'.

Finally, the leader of Brexit Party, Nigel Farage, conducted a subdued campaign, despite media premises of him as the potential main political actor. One of the reasons may have been the early decision that his party wouldn't contest hundreds of Conservative Party-held districts, boosting PM Johnson's chances of re-election. Indeed, before this decision, Johnson was the most attacked politician by Farage. For example, on 3 November 2019, he wrote: 'From tomorrow, I will be going out to campaign across the length and breadth of this country. We will explain to people why Boris' Brexit is a betrayal of the hopes of $17.4 \mathrm{~m}$. That means I have no time to fight a seat myself, but I will support 600 other people who are'. 
Nevertheless, his Twitter campaign was built around two communicative strategies: emotional and instrumental. In particular, Farage focused on typical right-wing issues related to security, introducing the terrorism topic after a terrorist knife attack in London at the end of November. On 30 November 2019, he declared: 'People will be very angry that a convicted terrorist was on the streets of London after a very short sentence. For Labour to say the attack happened because of police cuts is nonsense, weak sentencing and soft policies from both parties are the cause of this outrage'.

Also, it must be highlighted that Farage's people are mainly generic without a specific adjective to connote them. He had a 'contract with the people', as he declared on 9 December 2019, to give them 'a genuine choice in this election', as he wrote in a tweet on 5 November 2019. He directly appealed to the people, without borders, using them in an adversarial way to mark their distinction from the establishment, e.g. when on 17 October he described the EU as an institution that 'shows itself to be a thuggocracy - power without accountability', or when on 27 November 2019 he declared that Labour 'have broken their promises to the people and they deserve to be beaten at the ballot box'.

\section{Conclusion}

This paper shows that to properly understand today's people concept, an analysis of its meaning is required through a critical evaluation of how the word 'people' is used by leaders. More specifically, this contributes an empirical assessment of how, in a controversial period of UK political history, the foremost party leaders can appeal to their people, looking at them as a unified entity with legitimate power (Espejo 2011); a social body; and a socio-political group (Espejo 2017; Smith 2003; Urbinati 2019). Furthermore, depending on how the people are connoted through specific adjectives, the paper identified and empirically discussed how the people concept can attract different meanings and a political connotation (Badiou et al. 2013).

Indeed, although several scholars describe it as an 'empty signifier' (Laclau 2005) due to its objective flexibility, this study, following other approaches (Mudde 2004; Taggart 2000, 2004), considers 'the people' as not completely empty. This is due to the socio-cultural soul of the context, for example, or the construction of content by leaders based on the self-perception of features of target communities which share common ideals. Thus, while populism is considered here as a thin ideology, the paper also aims to understand its borders. As regards the results, the paper highlights three principal attitudes related to the connotation of 'the people' by the UK leaders. First, Johnson communicated with every (British) person, regardless of their political opinions, in order to have a single people to love, look after, and protect, and from whom he asked for legitimacy throughout the election campaign. The frontrunner institutionalized himself as having a paternalistic attitude, safeguarding and representing the real interests of his people. Simplistically, he created a vertical, direct and immediate relationship with the British people when it came close to polling day. 
Second, the group of leaders represented by Corbyn, Swinson, and Sturgeon was characterized by an identity-based pattern of communication: supporters, 'remainers', and Scottish. This attitude emphasizes what unifies the people within a specific circle rather than what differentiates them from those outside. This type of attitude describes the people as a strong, cohesive group. For example, Corbyn's campaign has been regarded as the part of politics that tries to represent everything by continually calling on its militants and supporters to remain united. Third, the people without borders of Farage was a communication strategy aimed at emphasizing the differences between the pure people and the corrupt elites. This attitude also uses the identity dimension but in a distinctive way to claim differences from those who are not included in that circle.

Thus, the results highlight three key attitudes related to the connotation of 'people'. The first considers a direct and immediate relationship between a leader and the whole people. The second is a calling to a specific people, described as a strong and cohesive community, which share the same ideals. The third is a set of people without borders, held together by cultural/moral values, contraposing pure people and the corrupt elite.

In this instance, in the first attitude, there are no clear elements of populism. This attitude was influenced also by the Conservatives' approach, which, as argued by several scholars, was built around a tight and controlled strategy able to avoid possible risks (Power et al. 2020). As regards the second attitude, it needs to consider separately Swinson's approach, where is difficult to assume that we are facing the populist phenomenon. The inability of the Liberal Democrats to burst through as a real centrist third party (Flinders 2020) can be blamed on poor campaign strategy, although there was a new core vote based on her people, the Remainers, and on the stronger polarization of public opinion for and against Johnson (Sloman 2020).

In two other leaders, the people are evident in different aspects, both relevant in understanding the populism of the left. The calling of the leaders to a self-perception of targeted communities is relevant in Corbyn and Sturgeon's 'people'. This also shows the fragility/thinness of the populist idea. Indeed, as argued by March (2017), in particular as regards the SNP, British left populists strongly overlap with the underlying ideology. This allows understanding of how in the last electoral campaign the host ideology was more important than the populism idea in explaining the essence of the phenomenon highlighted in this study's outcomes.

The Labour Party admittedly seems to be more contradictory. The key factor in this established party is the role of its leadership in recent years. Several scholars argue that Corbynism, as an extremely personalistic political leadership, instigated the party's leftward change, above all the view that Labour's members had to be considered as 'the people' (Watts and Bale 2019). Although other important research suggests that Labour's populist transformation by Corbyn has different doubtful aspects, including the Bennite traditionalism that seems more determinant (March 2017), the analysis shown in this paper seems to confirm Watts and Bale's findings. The key core around which Corbyn's galaxy orbits is 'the people' as a group of members. They are his legitimation, the heartland focused on past ideals against the (internal and external) elite conspiracy where the leader becomes the only possibility of a democratic solution. 
Finally, the third attitude is represented by Farage's 'people'. This populist antiEU campaigner has used Twitter since the beginning in an effective way. Several scholars show how his communication style appears both down-to-earth and emotive using provocations based on 'common sense' (Breeze 2020). Nigel Farage and others in general right-wing populism appropriate the voice of the people through a simplistic set of messages (Freeden 2017). His people are mainly generic people without a clear specification able to connote them, used in the rhetorical contraposition that differentiates themselves, and their leader, obviously, from the establishment. Given this type of scenario, it is certainly not surprising that Farage's 'people' was found to be closely associated with Mudde's dichotomy (2004).

Thus, this first analysis of 'people' provides a renewed understanding of the concept, above all under a populist perspective which emphasizes its thinness as an ideology. After all, populism can appear as 'self-limiting' and 'episodic' (Taggart 2000), showing a karstic trend. It runs underground, appearing periodically with explicit reference to particularly regrettable events, anchoring itself to a host as much as possible in a symbiotic relationship_parasitism, mutualism, commensalism, or whatever it is - to disappear until its next re-emergence.

Acknowledgements This article reflects only the author's views and the Research Executive Agency (REA) is not liable for any use that may be made of the information it contains. This project has received funding from the European Union's Horizon 2020 research and innovation programme under the Marie Skłodowska-Curie grant agreement No 838418.

Open Access This article is licensed under a Creative Commons Attribution 4.0 International License, which permits use, sharing, adaptation, distribution and reproduction in any medium or format, as long as you give appropriate credit to the original author(s) and the source, provide a link to the Creative Commons licence, and indicate if changes were made. The images or other third party material in this article are included in the article's Creative Commons licence, unless indicated otherwise in a credit line to the material. If material is not included in the article's Creative Commons licence and your intended use is not permitted by statutory regulation or exceeds the permitted use, you will need to obtain permission directly from the copyright holder. To view a copy of this licence, visit http://creativecommons.org/licen ses/by/4.0/.

\section{References}

Alvares, C., and P. Dahlgren. 2016. Populism, extremism and media: Mapping an uncertain terrain. European Journal of Communication 31 (1): 46-57.

Ausserhofer, J., and A. Maireder. 2013. National politics on Twitter: Structures and topics of a networked public sphere. Information, Communication \& Society 16 (3): 291-314.

Badiou, A., G. Didi-Huberman, J. Butler, P. Bourdieu, J. Rancière, and S. Khiari. 2013. Qu'est-ce qu'un peuple? Paris: La fabrique éditions.

Bos, L., and K. Brants. 2014. Populist rhetoric in politics and media: A longitudinal study of the Netherlands. European Journal of Communication 29 (6): 703-719.

Bos, L., W. Van der Brug, and C. De Vreese. 2010. Media coverage of right-wing populist leaders. Communications 35 (2): 141-163.

Bos, L., W. Van der Brug, and C. De Vreese. 2011. How the media shape perceptions of right-wing populist leaders. Political Communication 28 (2): 182-206.

Bos, L., W. Van Der Brug, and C.H. De Vreese. 2013. An experimental test of the impact of style and rhetoric on the perception of right-wing populist and mainstream party leaders. Acta Politica 48 (2): 192-208. 
Breeze, R. (2020). Exploring populist styles of political discourse in Twitter. World Englishes.

Caiani, M., and P.R. Graziano. 2016. Varieties of populism: Insights from the Italian case. Italian Political Science Review 46 (2): 243-267.

Canovan, M. 1981. Populism. New York: Harcourt Brace Jovanovich.

Canovan, M. 1999. Trust the people! Populism and the two faces of democracy. Political Studies 47 (1): $2-16$.

Canovan, M. 2005. The people. Cambridge: Polity Press.

Conway, B.A., K. Kenski, and D. Wang. 2015. The rise of Twitter in the political campaign: Searching for intermedia agenda-setting effects in the presidential primary. Journal of Computer-Mediated Communication 20 (4): 363-380.

Davis, R., C.H. Bacha, and M.R. Just, eds. 2016. Twitter and elections around the world: Campaigning in 140 Characters or Less. London: Routledge.

De la Torre, C. 2010. Populist seduction in Latin America. Athens: Ohio University Press.

De Luca, M., and Ciaglia, A. (2017). The role of the people in the characterization of populism. Evidence from the press coverage of the. 2014. European Parliament election campaign in Italy. Italian Political Science Review/Rivista Italiana di Scienza Politica 47 (1): 63-85.

Di Tella, T.S. 1997. Populism into the twenty-first century. Government and Opposition 32 (2): 187-200.

Engesser, S., N. Fawzi, and A.O. Larsson. 2017. Populist online communication: Introduction to the special issue. Information, Communication \& Society 20: 1279-1292.

Flinders, M. 2020. Not a Brexit election? Pessimism, promises and populism 'UK-style.' Parliamentary Affairs 73 (1): 225-242.

Freeden, M. 2017. After the Brexit referendum: revisiting populism as an ideology. Journal of Political Ideologies 22 (1): 1-11. https://doi.org/10.1080/13569317.2016.1260813.

Greenacre, M. 2017. Correspondence analysis in practice. Boca Raton: CRC Press.

Ionescu, G., and E. Gellner, eds. 1969. Populism: its meaning and national characteristics. New York: Macmillan.

Jacobs, K., and N. Spierings. 2016. Social media, parties, and political inequalities. Basingstoke: Palgrave Macmillan.

Jagers, J., and S. Walgrave. 2007. Populism as political communication style: An empirical study of political parties' discourse in Belgium. European Journal of Political Research 46 (3): 319-345.

Klinger, U., and J. Svensson. 2015. The emergence of network media logic in political communication: A theoretical approach. New Media \& Society 17 (8): 1241-1257.

Krämer, B. 2014. Media populism: A conceptual clarification and some theses on its effects. Communication Theory 24 (1): 42-60.

Kriesi, H., and T.S. Pappas, eds. 2015. European populism in the shadow of the great recession, 1-22. Colchester: ECPR Press.

Laclau, E. 2005. On populist reason. London: Verso.

March, L. 2012. Radical left parties in Europe. Abingdon: Routledge.

March, L. 2017. Left and right populism compared: The British case. The British Journal of Politics and International Relations 19 (2): 282-303.

Mazzoleni, G., J. Stewart, and B. Horsfield, eds. 2003. The Media and neo-populism: A contemporary comparative analysis. Westport, CT: Praeger.

Mény, Y., and Y. Surel. 2002. Democracies and the populist challenge. New York: Palgrave.

Moffitt, B., and S. Tormey. 2014. Rethinking populism: Politics, mediatisation and political style. Political Studies 62 (2): 381-397.

Mudde, C. 2004. The populist zeitgeist. Government and Opposition 39 (4): 541-563.

Mudde, C., and Kaltwasser, C. R. (Eds.). (2012). Populism in Europe and the Americas: Threat or corrective for democracy? Cambridge University Press, Cambridge

Mudde, C., and C.R. Kaltwasser. 2013. Exclusionary vs inclusionary populism: Comparing contemporary Europe and Latin America. Government and opposition 48 (2): 147.

Espejo, P.O. 2011. The time of popular sovereignty: Process and the democratic state. University Park: Pennsylvania State University Press.

Espejo, P. O. (2017). Populism and the idea of the people. In C.R. Kaltwasser, Taggart, P. A., Espejo, P. O., and Ostiguy, P. (eds.). (2017). The Oxford Handbook of Populism. Oxford: Oxford University Press.

Pauwels, T. 2014. Populism in Western Europe: Comparing Belgium, Germany and the Netherlands. London: Routledge. 
Power, S., T. Bale, and P. Webb. 2020. Mistake overturned, so I call it a lesson learned':1 The Conservatives. Parliamentary Affairs 73 (2): 65-83. https://doi.org/10.1093/pa/gsaa022.

Rooduijn, M. 2014. The nucleus of populism: In search of the lowest common denominator. Government and Opposition 49 (4): 573-599.

Rooduijn, M., S.L. De Lange, and W. Van der Brug. 2014. A populist Zeitgeist? Programmatic contagion by populist parties in Western Europe. Party Politics 20 (4): 563-575.

Sloman, P. 2020. Squeezed out? The liberal democrats and the 2019 general election. The Political Quarterly 91 (1): 35-42.

Smith, R.M. 2003. Stories of peoplehood: The politics and morals of political membership. Cambridge: Cambridge University Press.

Stanley, B. 2008. The thin ideology of populism. Journal of Political Ideologies 13 (1): 95-110.

Stanyer, J. 2012. Intimate politics: Politicians and declining privacy in the media age. Cambridge: Polity Press.

Taggart, P. 2000. Populism. Buckingham: Open University Press.

Taggart, P. 2004. Populism and representative politics in contemporary Europe. Journal of Political Ideologies 9 (3): 269-288.

Taguieff, P.A. 1995. Political science confronts populism: From a conceptual mirage to a real problem. Telos 1995 (103): 9-43.

Tromble, R. 2016. The great leveler? Comparing politician-citizen Twitter engagement in three Western democracies. European Political Science 1: 1-17.

Ubinati, N. 1998. Democracy and populism. Constellations 5 (1): 110-124.

Urbinati, N. 2019. Me the people: How populism transforms democracy. Cambridge-London: Harvard University Press.

Van Kessel, S. 2015. Populist parties in Europe: Agents of discontent? New York: Springer.

Van Santen, R., and L. Van Zoonen. 2010. The personal in political television biographies. Biography 33 (1): 46-67.

Watts, J., and T. Bale. 2019. Populism as an intra-party phenomenon: The British Labour party under Jeremy Corbyn. The British Journal of Politics and International Relations 21 (1): 99-115.

Weyland, K. 2001. Clarifying a contested concept: Populism in the study of Latin American politics. Comparative Politics 34 (1): 1-22.

Publisher's Note Springer Nature remains neutral with regard to jurisdictional claims in published maps and institutional affiliations. 